\title{
Social Cataloguing Sites: Features and Comparison in Relation to ISBD
}

\author{
Arindam Sarkar* and Udayan Bhattachrya \\ Department of Library and Information Science, Jadavpur University, Kolkata - 700032, West Bengal, India; \\ infoarindam83@gmail.com
}

\begin{abstract}
In the past few years, the number of social site related applications has increased; and also, these are playing an important role in the collection and sharing of knowledge. These types of application give users the freedom to create vocabulary, which helps to describe and categorize online resources. The social cataloguing applications are a type of web application that helps users to catalogue various items. These social cataloguing sites help users to catalogue their personal book collections, and make the collection known to all users with similar tastes. This study analyzed and evaluated the bibliographic and social features of some selected popular social cataloguing sites and also compared with the data elements prescribed in the International Standard Bibliographic Description (ISBD).
\end{abstract}

Keywords: International Standard Bibliographic Description (ISBD), Online Resources, Social Cataloguing

\section{Introduction}

Library catalogues, since their introduction, have become an important and fundamental medium between the library users and their information needs. The primary purpose of the library catalogue is to help users find specific titles, and/or resources by specified authors, or on specified subject matter from the library collection. But today's library catalogues are constantly competing with powerful options for information seeking and searching.

At present, if the library's catalogue has to continue to be relevant to its users, the catalogue will have to go out of its traditional model so that all the controls are not limited to the library staff, the user has to contribute as well.

A social cataloging application is a web application that helps users to catalog various items such as books, journals, CDs, etc. The social cataloguing is only five years old concept but has already reached a high level in present day environment. Users can catalogue various items by their own vocabulary or metadata or tags, which may be more acceptable to the other user.
The purpose of this study is to analyze, evaluate, and compare the bibliographic and social features of some selected popular social cataloguing sites.

\section{Literature Review}

Spiteri (2009) "examines and evaluates the social features and comprehensiveness of the catalogue records of 16 popular social cataloguing web sites to determine whether their social and cataloguing features could or should impact the design of library catalogue records". Author concluded that "the bibliographic content of most of the catalogue records examined was poor when assessed by professional cataloguing practice; their social features can help make the library catalogue a lively community of interest where people can share their reading interests with one another" (Spiteri, 2009).

Giustini, Hooker, Cho (2009) provide an overview of the trends in social cataloguing for health librarians. According to them "Social cataloguing allows members to not only share publicly their catalogued inventories, but to 
post reviews and commentaries on the items posted, create and participate in discussion groups, and tag or classify the items catalogued. In other words, these sites serve as a user designed, interactive, and shared catalogue" (Giustini, Hooker \& Cho, 2009).

\section{Objectives}

The objectives of the present study are as follows:

1. To study how social cataloguing sites presents their bibliographic record.

2. To explore the comprehensiveness of catalogue records in social cataloguing sites.

3. To identify the use pattern of metadata elements (e.g., title, author, publisher, ISBN etc.) for a document (e.g., book, CD/DVD etc.) in popular social cataloguing sites.

4. To compare the uses of metadata in the social cataloguing site with professional cataloging standard, and

5. To study the social features used in popular social cataloguing sites.

\section{Scope and Methodology}

For this study at first social cataloguing sites were selected from Wikipedia (https://en.wikipedia.org/wiki/ Social_cataloging_application) and its related reference links. Finally, 11 social cataloguing sites were chosen. For the purpose of this study, it was decided to examine only the bibliographic data of books. The bibliographic records were examined from selected social cataloguing sites $15^{\text {th }}$ to $20^{\text {th }}$ July 2019. Selected bibliographic records (books only) from social cataloguing sites were evaluated in respect of eight areas prescribed by the Anglo America Cataloguing Rules (AACR), which is based on ISBD and is widely used by professional cataloguers. Also, for more detailed evaluation eight areas were further broken down into their sub-parts. Also, others features of a bibliographic entry were examined by navigating each of the social cataloguing sites.

\section{Analysis}

In this study the bibliographic records of the book (from social cataloguing sites) were evaluated based on the standard International Standard for Bibliographic Description (ISBD) elements. These eight elements are used in the Anglo American Cataloguing Rules (AACR) standard which is generally used by professional cataloguers. These eight areas are as follows:

1. Title and statement of responsibility area,

2. Edition area,

3. Material (or type of publication) specific details area,

4. Publication, distribution, etc., area,

5. Physical description area,

6. Series area,

7. Note area, and

8. Standard number and terms of availability area.

For better study, the eight ISBD elements were further broken down into their individual constituent parts, as follows:

1. Title,

2. Author or Editor or Illustrator or Compiler etc.,

3. Edition,

4. Place of publication,

5. Publisher,

6. Date of publication,

7. Page number,

8. Size of book,

9. Series number,

10. Language note,

11. Other information about book or other notes, and 12. ISBN/ISSN

\subsection{List of Selected Social Cataloguing Sites}

As mentioned earlier 11 social cataloguing sites were chosen for this study. Sites are as follows:

Table 1. List of selected social cataloguing sites

\begin{tabular}{|c|l|l|c|}
\hline $\begin{array}{r}\text { Sl. } \\
\text { No. }\end{array}$ & $\begin{array}{c}\text { Social } \\
\text { Cataloguing } \\
\text { Site }\end{array}$ & \multicolumn{1}{|c|}{ URL } & Abbreviation \\
\hline 1. & aNobii & https://www.anobii.com/ & aN \\
\hline 2. & Bibliophil & http://www.bibliophil.org/ & BPhil \\
\hline 3. & BookBump & http://www.bookbump.com/ & BB \\
\hline 4. & $\begin{array}{l}\text { E-Books } \\
\text { Directory }\end{array}$ & $\begin{array}{l}\text { http://www.e-booksdirectory. } \\
\text { com/ }\end{array}$ & EBD \\
\hline 5. & eBookMall & $\begin{array}{l}\text { https://www.ebookmall.com/ } \\
\text { free-ebooks }\end{array}$ & eBM \\
\hline 6. & Goodreads & https://www.goodreads.com/ & $\mathrm{Gr}$ \\
\hline
\end{tabular}




\begin{tabular}{|c|l|l|c|}
\hline 7. & KaboBooks & https://www.kobo.com/ & $\mathrm{KB}$ \\
\hline 8. & LibraryThing & https://www.librarything.com/ & $\mathrm{LT}$ \\
\hline 9 & Readgeek & https://www.readgeek.com/ & $\mathrm{Rg}$ \\
\hline 10. & Smashwords & https://www.smashwords.com/ & $\mathrm{Sw}$ \\
\hline 11. & Weread & http://www.weread.org/ & $\mathrm{Wr}$ \\
\hline
\end{tabular}

\subsection{Availability of ISBD Elements of Books in Selected Social Cataloguing Sites}

Table 2 shows the availability of twelve broken elements, actually 8 ISBD elements within the selected social cataloguing sites.

Table 2. Availability of ISBD elements in selected social cataloguing sites

\begin{tabular}{|l|c|c|c|c|c|c|c|c|c|c|c|}
\hline \multirow{2}{*}{$\begin{array}{l}\text { ISBD } \\
\text { Elements }\end{array}$} & \multicolumn{10}{|c|}{ Name of the Social Cataloguing Sites } \\
\hline & aN & BPhil & BB & EBD & eBM & Gr & KB & LT & Rg & Sw & Wr \\
\hline Title & $\checkmark$ & $\checkmark$ & $\checkmark$ & $\checkmark$ & $\checkmark$ & $\checkmark$ & $\checkmark$ & $\checkmark$ & $\checkmark$ & $\checkmark$ & $\checkmark$ \\
\hline $\begin{array}{l}\text { Author } / \\
\text { Editor }\end{array}$ & $\checkmark$ & $\checkmark$ & $\checkmark$ & $\checkmark$ & $\checkmark$ & $\checkmark$ & $\checkmark$ & $\checkmark$ & $\checkmark$ & $\checkmark$ & $\checkmark$ \\
\hline Edition & $\checkmark$ & $\checkmark$ & x & x & $\checkmark$ & $\checkmark$ & $\checkmark$ & $\checkmark$ & x & x & $\checkmark$ \\
\hline Place & x & x & x & x & x & x & x & $\checkmark$ & x & x & x \\
\hline Publisher & $\checkmark$ & $\checkmark$ & $\checkmark$ & $\checkmark$ & $\checkmark$ & $\checkmark$ & $\checkmark$ & $\checkmark$ & $\checkmark$ & $\checkmark$ & $\checkmark$ \\
\hline $\begin{array}{l}\text { Date of } \\
\text { Publication }\end{array}$ & $\checkmark$ & $\checkmark$ & $\checkmark$ & $\checkmark$ & $\checkmark$ & $\checkmark$ & $\checkmark$ & $\checkmark$ & $\checkmark$ & $\checkmark$ & $\checkmark$ \\
\hline Page No. & $\checkmark$ & x & x & $\checkmark$ & $\checkmark$ & $\checkmark$ & $\checkmark$ & $\checkmark$ & x & x & x \\
\hline Size & x & $\checkmark$ & x & x & x & x & x & $\checkmark$ & x & x & x \\
\hline Series & x & x & x & x & $\checkmark$ & $\checkmark$ & $\checkmark$ & $\checkmark$ & $\checkmark$ & x & x \\
\hline Language & $\checkmark$ & $\checkmark$ & $\checkmark$ & x & $\checkmark$ & $\checkmark$ & $\checkmark$ & $\checkmark$ & $\checkmark$ & $\checkmark$ & $\checkmark$ \\
\hline $\begin{array}{l}\text { Other- } \\
\text { notes }\end{array}$ & $\checkmark$ & $\checkmark$ & $\mathrm{x}$ & $\checkmark$ & $\checkmark$ & $\checkmark$ & $\checkmark$ & $\checkmark$ & $\checkmark$ & $\checkmark$ & $\checkmark$ \\
\hline ISBN & $\checkmark$ & $\checkmark$ & $\checkmark$ & $\checkmark$ & $\checkmark$ & $\checkmark$ & $\checkmark$ & $\checkmark$ & $\checkmark$ & $\checkmark$ & $\checkmark$ \\
\hline
\end{tabular}

Table 2 reveals that 'Title', 'Author/Editor,' 'Publisher', 'Date of publication' and 'ISBN', these five (5) major elements are common to all (100\%) 11 social cataloguing sites. In most cases title and responsible person i.e. author or editor are hyperlinked, so users can navigate and find additional information. 'Language' and 'Othernotes' are two other data elements available in 10 (90.91\%) social cataloguing sites. Information about 'Edition', pagination and series are available in a few social cataloguing sites. 'Place' element is present in only one social cataloguing site, which is Library Thing. These bibliographic elements may be useful to users who are concerned about whether a book will meet their own purposes.

\subsection{Availability of Social Features in Selected Social Cataloguing Sites}

It is natural that the social features should be strong for social cataloguing sites. Table 3 shows the availability of social characteristics in selected sites.

Table 3. Availability of social features in selected social cataloguing sites

\begin{tabular}{|l|c|c|c|c|c|c|c|c|c|c|c|}
\hline \multirow{2}{*}{$\begin{array}{c}\text { Social } \\
\text { Features }\end{array}$} & \multicolumn{10}{|c|}{ Name of the Social Cataloguing Sites } \\
\hline & aN & BPhil & BB & EBD & eBM & Gr & KB & LT & Rg & Sw & Wr \\
\hline $\begin{array}{l}\text { Group } \\
\text { discussion }\end{array}$ & $\checkmark$ & $\checkmark$ & x & x & x & $\checkmark$ & x & $\checkmark$ & x & x & x \\
\hline Ratting & $\checkmark$ & $\checkmark$ & x & x & $\checkmark$ & $\checkmark$ & $\checkmark$ & $\checkmark$ & $\checkmark$ & x & x \\
\hline Reviews & $\checkmark$ & $\checkmark$ & $\checkmark$ & $\checkmark$ & $\checkmark$ & $\checkmark$ & $\checkmark$ & $\checkmark$ & $\checkmark$ & $\checkmark$ & $\checkmark$ \\
\hline Share & $\checkmark$ & $\checkmark$ & x & $\checkmark$ & $\checkmark$ & $\checkmark$ & $\checkmark$ & $\checkmark$ & $\checkmark$ & $\checkmark$ & $\checkmark$ \\
\hline $\begin{array}{l}\text { Tagging/ } \\
\text { Genre }\end{array}$ & $\checkmark$ & x & x & x & x & $\checkmark$ & $\checkmark$ & $\checkmark$ & $\checkmark$ & x & $\checkmark$ \\
\hline $\begin{array}{l}\text { User's } \\
\text { profile }\end{array}$ & $\checkmark$ & $\checkmark$ & $\checkmark$ & x & $\checkmark$ & $\checkmark$ & $\checkmark$ & $\checkmark$ & $\checkmark$ & $\checkmark$ & $\checkmark$ \\
\hline $\begin{array}{l}\text { Voting } \\
\text { option for } \\
\text { user }\end{array}$ & $\checkmark$ & $\checkmark$ & x & x & x & $\checkmark$ & $\checkmark$ & $\checkmark$ & $\checkmark$ & x & x \\
\hline
\end{tabular}

Table 3 shows that the 11 social cataloguing sites, only three sites, aNobii, Good reads and Library Thing, have all the social features.

\section{Conclusion}

Library Thing is a good example of a social catalogue, but it is not the only resource, there are other good examples like aNobii, Good reads, Kabo Books etc. These social cataloguing sites also have good social features like tagging, rating, reviewing, sharing etc.

\section{References}

Cavanaugh, T.W. (2007). Online Personal Book Cataloging. Florida Reading Quarterly, 44(2), Retrieved from http:// www.flreads.org/Publications/quarterly/samples/online_ book_catalog.htm.

Farrell, S. \& Lau, T. (2006). Fringe Contacts: People-Tagging for the Enterprise. Workshop on Collaborative Web Tagging, WWW 2006, Edinburgh, Scotland, May 22, 2006. Retrieved from http://tlau.org/research/papers/www06tagging-fc.pdf.

Giustini, D., Hooker, D. \& Cho, A. (2009). Social cataloguing: An overview for health librarians. JCHLA/JABSC, 30, 
133-38. Retrieved from https://www.academia. edu/19693267/Social_cataloguing_an_overview_for_ health_librarians, https://doi.org/10.5596/c09-039.

Spiteri, L.F. (2009). Social cataloguing sites: Features and implications for cataloguing practice and the public library catalogue. Cataloging and Classification Quarterly, 47(1), 5270. https://doi.org/10.1080/01639370802451991.

Spiteri, L.F. \& Laurel T. (2011). The Public Library Catalogue as a Social Space: A Case Study of Social Discovery Systems in Two Canadian Public Libraries. 2010 OCLC/ALISE Research Grant Report Published Electronically by OCLC Research. Retrieved from http://www.oclc.org/research/ grants/reports/2010/spiteri2010.pdf. 